45. Postacchini F (1989) Lumbar spinal stenosis. Springer, Berlin Heidelberg New York

46. Quint U, Adelt D (1995) Erfahrungen bei kombinierten Eingriffen an der lumbalen Wirbelsäule. Unfallchirurgie $4: 167-174$

47. Quint U, Adelt D (1995) Spinal canal stenosis - its differentiation and surgical treatment. Presented at the Seventh International Conference on Lumbar Fusion and Stabilization, Budapest, Thursday, October 26, 1995, abstract book $\mathrm{p} 10$

48. Quint U, Müller RT, Hövel M, Adelt D (1995) Vorteile und Nachteile beim trans- oder retroperitonealen Zugang zur lumbalen Wirbelsäule. Orthop Praxis $31: 24-27$

49. Robinson M, Cassisi J, Connor P, MacMillan M (1992) Lumbar iEMG during isotonic exercise: chronic low back pain patients versus controls. J Spinal Disord 5: 8-15

50. Sachs L (1992) Angewandte Statistik, 7th edn. Springer, Berlin Heidelberg New York

51. Schröder S, Lackner K, Anders G, Vogeler B (1982) Die lumbale Spinalkanalstenose. Z Orthop 120:134-145

52. Schulitz K (1995) Risk of instability following decompression surgery for lumbar spinal stenosis. Z Orthop 133: 236-241

53. Shenkin H, Hash C (1979) Spondylolisthesis after multiple bilateral laminectomies and facetectomies for lumbar spondylosis. J Neurosurg 50 : $45-47$
54. Skalli W, Robin S, Lavaste F, Dubousset J (1993) A biomechanical analysis of short segment spinal fixation using a three-dimensional geometric and mechanical model. Spine 18:536-545

55. Spengler D (1987) Current concepts review. Degenerative stenosis of the lumbar spine. J Bone Joint Surg [Am] 69:305-308

56. Steffen T, Rubin R, Baramki H, Antoniou J, Marchesi D, Aebi M (1997) New technique for measuring lumbar segmental motion in vivo. Spine 22 : 156-166

57. Strauss P, Novotny J, Wilder D, Grobler L, Pope M (1994) Multidirectional stability of the Graf system. Spine 19 : 965-972

58. Strempel von A (1995) Biomechanics of spinal implants: Rigid versus dynamic procedures. J Bone Joint Surg [Br] 77 [Suppl II] : 150

59. Strömqvist B, Johnsson R, Axelsson P (1996) Mobility provocation of lumbar fusion evaluated by roentgen. Stereophotogrammetric analysis. J Bone Joint Surg [Br] 78 [Suppl 1]: 47

60. Surin V, Hedelin E, Smith L (1982) Degenerative lumbar spinal stenosis. Acta Orthop Scand 53:79-85

61. Tanii K, Masuda T (1985) A kinesiologic study of erectores spinae activity during trunk flexion and extension. Ergonomics 28: 883-893

62. Tsou P (1985) Progressive symptomatic lumbar spondylolisthesis after decompressive laminectomy for acquired degenerative stenosis. Presented at the Annual Meeting of American Acaderny of Orthopaedic Surgeons, Las Vegas 1985
63. Van Akkerveeken P (1994) A taxonomy of lumbar stenosis with emphasis on clinical applicability. Eur Spine J 3 : 130-136

64. Verbiest H (1977) Results of surgical treatment of idiopathic developmental stenosis of the lumbar vertebral canal. J Bone Joint Surg [Br] 59:181-188

65. White A, Panjabi M (1990) Clinical biomechanics of the spine, 2nd edn. Lippincott, Philadelphia

66. Wiesner L, Rüther W, Fink B ( 1995) A new method for measurement of segmental motion behaviour at the lumbar spine. J Bone Joint Surg [Br] 77 [Suppl II] : 161

67. Wilcoxon F (1945) Individual comparisons by ranking methods. Biometrics $1: 80-83$

68. Wilke H-J, Claes L, Schmitt H, Wolf S (1994) A universal spine tester for in vitro experiments with muscle force simulation. Eur Spine J 3:91-97

69. Wilke H-J, Ostertag G, Claes L (1994) Dreidimensionales Goniometermesssystem zur Analyse von Bewegungen mit sechs Freiheitsgraden. Biomed Technik 39: 149-155

70. Wilke H-J, Wolf S, Claes L, Arand M, Wiesend A (1996) Influence of varying muscle forces on lumbar intradiscal pressure: an in vitro study. $\mathbf{J}$ Biomech 29:549-555

71. Wilke H-J, Wolf S, Claes L, Arand M, Wiesend A (1995) Stability increase of the lumbar spine with different muscle groups. Spine 20:192-198

\title{
REVIEWER'S COMMENT
}

The authors have performed an in vitro biomechanical study of the effect of laminectomy on the function of the lumbar spine. They found that ligamentoplasty corrected the instability created by a laminectomy. While the study has been well conducted and the results analyzed with care, some important comments must be made. First, the authors assume that in cases of central and/or lateral stenosis, the standard procedure is laminectomy. Although they are right in stating that "so far no consensus has been reached on how much of the vertebral structures should be removed," they still assume that complete laminectomy is the way to go and therefore applied that procedure in their experimental set-up. State-of-the-art decompressions, how-

R. Gunzburg

Eevwfeestkliniek, Harmoniestraat 68, B-2018 Antwerp, Belgium ever, respect the vertebral arch, and only partial facetectomy is performed whenever possible. Complete laminectomy as described here is only seldom needed, and destabilization of the spine after decompression should certainly not be the rule. A second and perhaps even more specific criticism of the conclusions of this paper resides in the fact that only L4 laminectomy was performed. Most often decompression has to be performed at more than one level. To what extent the results with the laminoplasty as presented here can be extrapolated to a multilevel destabilization is unknown. The conclusion that "ligamentoplasty seems to be an alternative to decompression with spondylodesis" is therefore misleading. The authors should extend their experimentation to multilevel decompressions and combine the biomechanical study with a controlled, prospective trial comparing the different techniques in clinical practice. 